\title{
The role of endoscopic mucosal resection in gastrointestinal precancerous lesions
}

\author{
Gastrointestinal prekanseröz lezyonlarda endoskopik mukozal rezeksiyonun rolü
}

Suleyman ORMAN, Orhan GULTEKIN

\begin{abstract}
Objectives: Endoscopic mucosal resection (EMR) has been widely used in early gastrointestinal malignancies and precancerous lesions. We aim to analyze the outcomes of EMR for gastrointestinal precancerous lesions.

Materials and Methods: A total of 1,518 cases were retrospectively analyzed. Of these, 59 patients had undergone EMR for gastrointestinal lesions. The lesions were divided into two subgroups according to size; smaller than $20 \mathrm{~mm}$ and equal or larger than $20 \mathrm{~mm}$. The mucosal aspect (Kudo pit pattern), Paris classification of the resected lesions and recurrences that were determined during close follow-up were recorded.

Results: A total of 94 polyps were resected in 59 patients. En-block resection was performed in $42(71.2 \%)$ patients and piecemeal resection in $17(28.8 \%)$. There was no significant difference between two modalities; regarding age, gender, histopathology, complications, recurrence or macroscopic type $(P>0.05)$. However, the occurrence of Kudo type 4 lesions and adenomatous polyps $(P=0.001)$ was significant in the $>20 \mathrm{~mm}$ group $(P=0.03)$.

Conclusion: Endoscopic mucosal resection is a safe and feasible procedure for precancerous lesions, with low complication and acceptable recurrence rates. Additionally, the Kudo pit pattern should be taken into consideration on a routine basis when determining the risk of cancer.
\end{abstract}

Keywords: Endoscopic mucosal resection, Gastrointestinal precancerous lesion, Pit pattern, Recurrence

\footnotetext{
Suleyman Orman (四)

Gastrointestinal Surgery Clinic, Göztepe Research and Training Hospital, Istanbul Medeniyet University, Kadikoy, Istanbul, Turkey

e-mail: suleymanorm@hotmail.com

Orhan Gultekin

Istanbul Gastroenterology Center, Şişli, Istanbul, Turkey
}

Submitted / Gönderilme: 27.02.2017

Accepted/Kabul: 11.04 .2017
Öz

Amaç: Gastrointestinal maligniteler ve prekanseröz lezyonlarda endoskopik mukozal rezeksiyon (EMR) yaygın olarak kullanılmaktadır. $\mathrm{Bu}$ çalışmada amacımız gastrointestinal prekanseröz lezyonların tedavisinde EMR'un etkinliğini değerlendirmektir.

Araç ve Gereçler: Binbeşyüz onsekiz hasta retrospektif olarak incelendi. Toplamda 59 hastaya EMR uyguland1. Lezyonlar 20 mm'den büyük ve $20 \mathrm{~mm}$ ve küçük olmak üzere 2 gruba ayrıldı. Mukozal görünüş ( Kudo pit patern yapısı) ve Paris sınıflamalarına göre lezyonlar kaydedildi. Hastalardan iki işlem denemesine rağmen polipleri tam çıkarılamayanlar cerrahiye yönlendirildi ve bu çalışmaya alınmadı. Yakın takipler esnasında saptanan tekrarlar kaydedildi.

Bulgular: Elli dokuz hastadan toplam 94 polip rezeke edildi. Hastaların 42 ( \%71,2)' sine enblok, 17 (\%28,8)'sine ise piecemeal rezeksiyon uygulandi. İki yöntem arasında yaş, cinsiyet, histopatoloji, komplikasyonlar, tekrar ve makroskobik tipler açısından farklılık gözlenmedi $(P>0,05) .20 \mathrm{~mm}$ 'den büyük poliplerde Kudo tip 4 görünüş ve adenomatöz polipler $(P=0,001)$ yaygin olarak izlendi $(P=0,03)$.

Sonuçlar: Prekanseröz lezyonlarda EMR işlemi düşük komplikasyon ve kabul edilebilir tekrar oranları ile güvenli ve kullanışlı bir işlemdir. Kudo pit patern yapısı kanser riski değerlendirilmesinde rutin olarak kullanılmalıdır.

Anahtar kelimeler: Endoskopik mukozal rezeksiyon, Gastrointestinal prekanseröz lezyon, Pit paterni, Nüks

\section{Introduction}

The use of endoscopic mucosal resection (EMR) was pioneered in Japan for the treatment of early gastric cancer and has been widely used in treating other early gastrointestinal malignancies and precancerous lesions [14].

Early endoscopic detection and removal of gastrointestinal precancerous lesions reduce the incidence of 
gastrointestinal malign neoplasias [5]. It has recently been shown that colonoscopic polypectomy significantly reduces the incidence of colorectal cancer associated with mortality [6]. Cancer screening programs, which are currently broadly implemented, can facilitate the detection of cancers at a curable stage, also help to diagnose more precancerous lesions. The increase in the detection of precancerous lesions, brings with it the need for more treatment facilities and optimal treatment techniques to facilitate cost-effective care. Endoscopic treatment of gastrointestinal precancerous lesions may prevent the need for surgical interventions such as segmental resection, wedge resection, hemicolectomy, eosophagectomy and gastrectomy with their associated complications. The resection of polyps can be performed en-bloc or piecemeal, according to the size and location of the lesion. Large adenomas require treatment beyond simple loop polypectomies or single-piece EMR, with the piecemeal method being the most common endoscopic resection technique used for them. However, piecemeal resection often leads to high rates of residual adenoma found during the follow-up period [7]. Two recently published prospective studies on the piecemeal EMR of colorectal adenomas, report residual adenoma rates as 20 $38 \%$, although, late recurrence was eventually diagnosed in less than $5 \%$ of these patients $[8,9]$. A previous systematic review, including 20 studies on EMR of large $(>2 \mathrm{~cm})$ colorectal adenomas, described an early recurrence rate of $11.2 \%$ (after a single attempt), where the lesions were in fact residual adenomas rather than actual recurrences. If those adenoma remnants were re-treated within 6 months, the late recurrence rate then dropped to $1.5 \%$ and complication rates were $3.8 \%[10]$.

In many countries, EMR is considered a complex endoscopic procedure and is usually only performed at specific centers to preserve its effectiveness and safety [11]. However, the complication rate associated with EMR is low [12]; the most frequent adverse effect is bleeding [13-17], followed by perforation $[3,18,19]$, as well as recurrence [1517,20]. Consequently, the use of EMR for gastrointestinal precancerous lesions has become increasingly popular in Western countries and has been found to be a safe and efficient treatment. This technique is not commonly practiced in rural hospitals in Turkey and most reports come from large tertiary referral practices. The aim of this present study is to retrospectively analyse the outcomes of EMR for gastrointestinal precancerous lesions with a particular focus on procedural complications and recurrence rates in two centers in Turkey.

\section{Material and Methods}

After being approved by the ethical board of Istanbul Medeniyet University, Göztepe Research and Training Hospital (2015/0140), a total of 1,518 patients who were referred to Istanbul Medeniyet University, Göztepe Research and Training Hospital and Istanbul Gastroenterology Centers for upper and lower gastrointestinal endoscopy between January 2011 and January 2015, were retrospectively analyzed. Only those patients with lesions suitable for EMR were included in the study. EMR procedures were performed on 59 patients by two endoscopists. Before the EMR, Kudo pit pattern type and Paris classification of all lesions were recorded [21,22]. Lesion size was endoscopically estimated using open biopsy forceps or a resection snare, although as some lesions were resected using the piecemeal method, an accurate size could not be calculated. Lesions were divided into two subgroups: those smaller than $20 \mathrm{~mm}(<20 \mathrm{~mm})$ and those equal/larger than $20 \mathrm{~mm}(\geq 20 \mathrm{~mm})$. Patients were excluded from the study if the mucosa was non-lifting or if there was any suspicion of submucosal invasion during diagnostic medical tests including computed tomography, magnetic resonance imaging or endoscopic ultrasonography. Patients that fulfilled all criteria were advised to undergo endoscopic treatment, additionally routine informed consents were obtained before each procedure.

\section{Resection method}

Before the endoscopic procedure, a split dose bowel preparation was used for the lower gastrointestinal area. Anticoagulant therapy was normally discontinued three days prior to the procedure. At the endoscopist's discretion, either conscious or deep sedation was administered using midazolam or propofol. Diagnostic endoscopes such as GIF-H180 or GIFHQ180: Olympus, Tokyo, Japan and VP4400 with XL 4400: Fujinon, Tokyo, Japan were preferred for the procedure. EMR was performed with polypectomy snares. Standard large (30mm: Boston Scientific, Natick, Massachusetts, USA); barbed (20mm: Olympus, Tokyo, Japan); or standard small (13 mm: Boston Scientific, Natick, Massachusetts, USA) snares were used in the piecemeal resection type. After proper endoscopic visualization of a lesion, it was lifted by injecting a large volume (10-100 $\mathrm{mL}$ ) of a pre-mixed solution submucosally, using a saline solution of $0.9 \%, 1 \mathrm{~mL}$ methylene blue and 1:10,000 units of adrenaline. Lesion margins were not routinely marked with mucosal cautery. The open snare was placed around the lesion and was gently pressed against the mucosa. The 
aim was to resect the lesions in one single piece rather than piecemeal, if possible. After the snare excision, air was insufflated to visualize the area of resection and, if needed, any further residual tissue was removed with a similar technique. Snare resection was continued until the lesion was macroscopically entirely removed, and the blue colored submucosa was visible. The settings used were "auto-cut" at a set power of $120 \mathrm{~W}$, along with the "endo-cut" mode. After resection, adjuvant heater probe coagulation therapy was used to remove any tiny visible remnants of lesions. There was no prophylactic treatment of visible vessels in the EMR defect; that were not bleeding and polypectomy sites were not closed with clips. Patients were discharged after the procedure.

\section{Histopathological evaluation}

After retrieval, whenever possible the size of the lesions was estimated by comparison and using open biopsy forceps. All removed tissue was retrieved using a retrieval basket, grasper or through the suction channel. All retrieved lesions were examined and classified by several experienced pathologists at the respective histopathology departments of each center. Polyps were classified as adenoma, intramucosal carcinoma or non-adenoma (e.g. hyperplastic polyps, leiomyoma, neuroendocrine tumour, lipoma, gastric mucosa). Adenomas were further classified for grade of dysplasia (i.e. low, or high-grade) using a combination of variables, including tubule configuration, nuclear polarity, orientation and structure, mucin content and location, etc, according to the Konishi-Morson system. [23]. The diagnosis of intramucosal carcinoma included adenomas with neoplastic cells invading the lamina propria mucosa $[24,25]$. It was impossible to evaluate the resection margins in piecemeal resection specimens; thus, only the basal margins, lesion type, and degree of dysplasia were assessed in these cases. When submucosally invasive carcinoma was diagnosed in the resection specimen, the necessity for additional treatment was discussed by a multidisciplinary team, and the patient was excluded from the study.

\section{Follow-up and recurrence}

Surveillance endoscopies were performed at various intervals of the follow up period. All patients underwent repeat endoscopies 3 months later and surveillance endoscopies were scheduled at $6,12,24$ and 36 months after EMR. During endoscopic follow-up, any alterations in the mucosa of the resection area (scarring, retractions of mucosa, etc.) were biopsied. If the scar appeared visibly normal, without the presence of adenomatous tissue, random biopsies were taken from its center and its edges. Recurrence was defined as the presence of adenomatous or polypoid tissue in a single follow-up endoscopy. All remnants and recurrences were treated endoscopically, if practical.

\section{Statistical analysis}

Data analysis was performed using Number Cruncher Statistical System (NCSS) 2007 (NCSS, LLC Kaysville, Utah, USA). Descriptive statistics for continuous variables were shown as mean \pm standard deviation or median (minimum-maximum), and categorical variables were shown as both the number and percentage of cases. Significant differences between the groups; in terms of mean value were analyzed with Student's t-test while median value differences were analyzed with the Mann-Whitney U test. Categorical variables were assessed by Pearson's chisquare test, Fisher's Exact test and Fisher Freeman Halton test. A $P$ value less than 0.05 was considered statistically significant.

\section{Results}

In total, 94 polyps in 59 patients were treated. Of these, 30 polyps were large gastrointestinal precancerous lesions (mean diameter $>20 \mathrm{~mm}$ ) with 19 patients having more than one lesion. 55 patients $(76.3 \%)$ had lesions localized in the colon and rectum area; 14 patients $(23.7 \%)$ had lesions in the stomach. En block resection was performed in $42(71.2 \%)$ patients; piecemeal resection in $17(28.8 \%)$. Macroscopically, lesions were protruding in 47 patients (79.7\%), superficial in 8 patients $(13.6 \%)$, and lateral spreading in the remaining 4 patients $(6.8 \%)$. According to Paris classification grading, $1 \mathrm{p}, 1 \mathrm{~s}$ and $2 \mathrm{a}$ grades were seen in $50(84.7 \%), 8(13.6 \%)$, and 1 patients $(1.7 \%)$, respectively. Kudo pit patterns were as follows: type 4 24 patients (39.0\%); 3L - 21 patients (35.6\%); 2 out of 11 patients $(18.6 \%)$ had type 2 ; and 4 patients $(6.8 \%)$ had $3 \mathrm{~S}$. The characteristics of the patient population, including the polyp size and location, are presented in Table I. Complete resection was achieved in 56 patients ( $95 \%$ ) while incomplete polyp resection in 3 patients required repeated sessions. One patient had significant bleeding during polypectomy and after no response to hemostatic interventions, underwent right hemicolectomy. 
Table I: Demographics and clinical characteristics

\begin{tabular}{|c|c|c|}
\hline \multirow[t]{2}{*}{$\begin{array}{l}\text { Age (years), } \\
\text { Duration of process (min) }\end{array}$} & \multicolumn{2}{|c|}{$\begin{array}{c}62.54 \pm 12.31 \\
13(2-66)\end{array}$} \\
\hline & $\mathbf{n}$ & $\%$ \\
\hline \multicolumn{3}{|l|}{ Gender } \\
\hline Male & 24 & 40.7 \\
\hline Female & 35 & 59.3 \\
\hline \multicolumn{3}{|l|}{ Pathology } \\
\hline Non-adenomatous & 16 & 27.1 \\
\hline Adenomatous & 43 & 72.9 \\
\hline \multicolumn{3}{|l|}{ Type of adenomatous polyp } \\
\hline Tubular Adenoma & 17 & 39.5 \\
\hline Tubulovillous Adenoma & 20 & 46.5 \\
\hline Villous Adenoma & 6 & 14.0 \\
\hline \multicolumn{3}{|l|}{ Localization } \\
\hline Stomach & 16 & 27.1 \\
\hline Colon & 28 & 47.5 \\
\hline Rectum & 15 & 25.4 \\
\hline Complication & 1 & 1.7 \\
\hline Recurrence & 2 & 3.4 \\
\hline \multicolumn{3}{|l|}{ Dimension of lesion } \\
\hline$<20 \mathrm{~mm}$ & 29 & 49.2 \\
\hline$\geq 20 \mathrm{~mm}$ & 30 & 50.8 \\
\hline \multicolumn{3}{|l|}{ Macroscopy } \\
\hline Superficial & 8 & 13.6 \\
\hline Protruding & 47 & 79.7 \\
\hline Lateral Spreading Type & 4 & 6.8 \\
\hline \multicolumn{3}{|l|}{ Technique } \\
\hline En-block & 42 & 71.2 \\
\hline Piecemeal & 17 & 28.8 \\
\hline \multicolumn{3}{|l|}{ Paris classification } \\
\hline $1 p$ & 50 & 84.7 \\
\hline $1 s$ & 8 & 13.6 \\
\hline $2 a$ & 1 & 1.7 \\
\hline \multicolumn{3}{|l|}{ Kudo classification } \\
\hline 2 & 11 & 18.6 \\
\hline $3 \mathrm{~L}$ & 21 & 35.6 \\
\hline $3 \mathrm{~S}$ & 4 & 6.8 \\
\hline 4 & 23 & 39.0 \\
\hline
\end{tabular}

The median follow-up period was 12 months (6-36 months). Local recurrence was recorded in two patients (3.4\%), at the sixth month with a histopathological pattern of low-grade displasia. Remnant adenomatous tissue was found during follow-up in 2 of the 59 patients (3.4\%).

Adenomatous polyps were found in thirty-seven patients (62.7\%) with low-grade dysplasia in 26 patients (44.1\%), and high-grade dysplasia in the remaining $11(18.6 \%)$. There were twenty-two patients $(27.3 \%)$ with non-adenomateous polyps: these comprised $11(18.6 \%)$ hyperplastic polyps; $6(10.2 \%)$ intramucosal cancers; 2 (3.4\%) regular gastric mucosa; 1 (1.7\%) neuroendocrine tumor; 1 (1.7\%) leiomyom and $1(1.7 \%)$ lipom.

Age, gender, histopathology, complications, recurrence or macroscopic type were not predictive values for the adoption of en-block or piecemeal resection $(P>0.05)$. 
However, en-block resection was more frequently used for lesions of the stomach, whereas piecemeal resection was associated with rectal lesions $(P=0.042)$. Piecemeal resection usage was also significantly higher in lesions $\geq 20 \mathrm{~mm}$ ( $P=0.001$ ), (Table II), and the duration of this procedure was significantly longer $(P=0.001)$.

No significant difference was found between en-block and piecemeal resection according to Paris and Kudo classifications $(P>0.05)$, (Table III).
The prevalence of Kudo type 4 lesions and adenomatous polyps $(P=0.001)$ was significantly associated with lesions $\geq 20 \mathrm{~mm}(P=0.03)$. Kudo type 2 lesions were more frequent in the stomach with type 4 lesions more common in the rectum ( $P=0.001$ ), but the distribution of colonic lesions according to Kudo types was not significantly different $(P>0.05)$. Meanwhile, a significant association was found between the subgroups of adenomatous polyps and their Kudo classification type $(P=0.02)$, (Table IV).

Table II: Comparison of the techniques

\begin{tabular}{|c|c|c|c|}
\hline & En-block $(n=42)$ & Piecemeal $(n=17)$ & $\boldsymbol{P}$ \\
\hline Gender & & & ${ }^{\mathrm{a}} 0.088$ \\
\hline Male & $20(47.6)$ & $4(23.5)$ & \\
\hline Female & $22(52.4)$ & $13(76.5)$ & \\
\hline Age (years) & $62.79 \pm 12.93$ & $61.94 \pm 10.98$ & ${ }^{\mathrm{b}} 0.814$ \\
\hline Pathology & & & ${ }^{\mathrm{d}} 0.115$ \\
\hline Non-adenomatous & $14(33.3)$ & $2(11.8)$ & \\
\hline Adenomatous & $28(66.7)$ & $15(88.2)$ & \\
\hline Localization & & & ${ }^{\mathrm{e}} \mathbf{0 . 0 4 2}$ \\
\hline Stomach & $14(33.3)$ & $2(11.7)$ & \\
\hline Colon & $21(50.0)$ & $7(41.2)$ & \\
\hline Rektum & $7(16.7)$ & $8(47.1)$ & \\
\hline Complication & & & ${ }^{\mathrm{d}} 1.00$ \\
\hline Yes & $1(2.4)$ & 0 & \\
\hline No & $41(97.6)$ & $17(100.0)$ & \\
\hline Recurrence & & & ${ }^{\mathrm{d}} 1.00$ \\
\hline Yes & $2(4.8)$ & 0 & \\
\hline No & $40(95.2)$ & $17(100.0)$ & \\
\hline Dimension of lesion & & & ${ }^{\mathrm{a}} \mathbf{0 . 0 0 1}$ \\
\hline$<20 \mathrm{~mm}$ & $29(69.0)$ & 0 & \\
\hline$\geq 20 \mathrm{~mm}$ & $13(31.0)$ & $17(100.0)$ & \\
\hline Duration of process (min) & $2-45(10.5)$ & $3-66(22)$ & ${ }^{\mathrm{c}} \mathbf{0 . 0 0 1}$ \\
\hline Macroscopy & & & ${ }^{\mathrm{e}} 0.127$ \\
\hline Superficial & $6(14.3)$ & $2(11.8)$ & \\
\hline Protrude & $35(83.3)$ & $12(70.6)$ & \\
\hline Spreading Type & $1(2.4)$ & $3(17.6)$ & \\
\hline
\end{tabular}


Table III. Comparison of techniques according to Paris and Kudo classifications

\begin{tabular}{cccr}
\hline & En-block (n=42) & Piecemeal (n=17) & $\boldsymbol{P}$ \\
\hline Paris classification & & & \\
$1 p$ & $36(85.7)$ & $14(82.4)$ & \\
$1 s$ & $5(11.9)$ & $3(17.6)$ & \\
$2 a$ & $1(2.4)$ & 0 & \\
Kudo classification & & & \\
2 & $9(21.4)$ & $2(11.8)$ & \\
$3 \mathrm{~L}$ & $18(42.9)$ & $3(17.6)$ & \\
$3 \mathrm{~S}$ & $2(4.8)$ & $2(11.8)$ & \\
4 & $13(31.0)$ & $10(58.8)$ & \\
\hline
\end{tabular}

${ }^{\mathrm{e}}$ Fisher Freeman Halton Test

\section{Discussion}

Several studies have been published regarding the safety and therapeutic potential of the endoscopic resection of gastrointestinal precancerous lesions. The most frequently reported adverse complication of EMR is bleeding, occurring in $1 \%$ to $45 \%$ of all cases [13-17] and the perforation rate has been reported as between $0.7 \%$ and $4 \%[3,18,19]$. Our complication rate (intraprocedural bleeding) in this present study was $1.7 \%$. Generally, complication rates of EMR are lower than those who undergo open surgery $(2.3 \%$ to $6.3 \%$ ) and comparable to those undergoing laparoscopic surgery ( $1.9 \%$ to $6.9 \%)$ [26]. Moreover, mean hospital stay for the patients who undergo colorectal surgery is 9.2-13.2 days and gastric surgery is 5.9-12.1 days, both significantly longer than EMR procedures which are usually performed as day cases [26,27]. Therefore, EMR is a good alternative to surgery in selected patients, especially as all lesions can frequently be removed in a single session, eliminating the discomfort for patients of repeated procedure. This was achieved in $95 \%$ of resections in the present study.

En-block resection is usually preferred to piecemeal resection, because it provides more accurate histological assessment and reduces the risk of local recurrence [28]. However, in the present study there were two recurrences (3.4\%), with no significant difference found in the recurrence rate data between the two resection techniques used. Clearly, follow-up is essential due to the risk of recurrence; aggressive monitoring seems justified, as animal research has shown that residual tumor has a high re-growth rate [29]. All patients in the present study had follow-up upper and lower gastrointestinal endoscopy. A wide range of recurrence rates after EMR of colorectal polyps and gastric polyps has been previously reported: between $0 \%$ and $46 \%[15-17,30,20]$. In the present study, our recurrence rate was $3.4 \%$ for gastrointestinal precancerous lesions. Several studies have suggested that the size of polyps is associated with recurrence [31-34]; however, no relation was found in the present study, suggesting that EMR can be carried out safely and effectively for gastrointestinal precancerous lesions. However, strict follow-up may be required for histologically advanced lesions due to a higher risk of recurrence.

This two-center study provides a faithful reflection of current daily practice in Turkey. Subsequent endoscopic follow up and treatment of adenoma remnants was possible in $100 \%$ of the patients. The recurrence and complication rates in our study compared favorably with previously published data on large gastrointestinal EMRs. Moss et al. demonstrated the feasibility of piecemeal EMR in colorectal adenomas, reporting very high case-volumes in a multicenter collaboration. Their results (early recurrence rate 20.4\%; morbidity $7.7 \%$ ) have established a sound standard for future endoscopists pursuing similar proficiency [9].

According to a recent study by Buchner et al., larger polyp size and the piecemeal nature of the resection were independent predictors of recurrence and complication [8]. In our study, we had just two recurrences and tumor size was not predictive of any recurrence or complication. This could be related to the prevalence of small sized lesions compared to large sized lesions and more frequent 
Table IV. Association of Kudo classification with lesion characters

\begin{tabular}{|c|c|c|c|c|c|}
\hline & \multicolumn{4}{|c|}{ Kudo classification } & \multirow[t]{2}{*}{$P$} \\
\hline & 2 & $3 \mathrm{~L}$ & $3 \mathrm{~S}$ & 4 & \\
\hline Dimension & & & & & $* 0.030$ \\
\hline$<20 \mathrm{~mm}$ & 7 & 14 & 2 & 6 & \\
\hline$\geq 20 \mathrm{~mm}$ & 4 & 7 & 2 & 17 & \\
\hline Localization & & & & & 0.001 \\
\hline Stomach & 7 & 8 & 1 & - & \\
\hline Colon & 3 & 9 & 3 & 13 & \\
\hline Rectum & 1 & 4 & - & 10 & \\
\hline Pathology & & & & & 0.001 \\
\hline Adenomatous & 4 & 14 & 3 & 22 & \\
\hline Non-adenoma & 7 & 7 & 1 & 1 & \\
\hline Type of polyp & & & & & 0.022 \\
\hline Tubular Adenoma & 4 & 8 & - & 5 & \\
\hline Tubulovillous Adenoma & 0 & 4 & 2 & 14 & \\
\hline Villous Adenoma & 0 & 2 & 1 & 3 & \\
\hline Paris classification & & & & & 0.020 \\
\hline $1 p$ & 10 & 19 & 1 & 20 & \\
\hline $1 s$ & 1 & 1 & 3 & 3 & \\
\hline $2 a$ & - & 1 & - & - & \\
\hline
\end{tabular}

*Fisher Freeman Halton Test

en-block resections. Non-adherence to protocols regarding the use of argon plasma coagulation (APC) has influenced recurrence rates in some studies; and previous studies have shown contradictory results regarding the effects of APC on adenoma recurrence $[9,35]$. In our study, a heater probe was used for the residue lesion areas.

Remnant or recurrent adenomatous tissue may be present as dysplasia in random biopsies of an apparently healed mucosectomy scar. This may be explained by the fact that chromoendoscopy or virtual chromoendoscopylike narrow band imaging are not routinely used for the detection of dysplastic lesions located in the scar. Moreover, in the 2 recurrences we detected, the adenomatous tissue might well have been missed during the prior endoscopy due to insufficient imaging, poor bowel preparation or localization behind a fold. Undoubtedly, strict monitoring with high quality endoscopes is essential in the follow-up period of these patients.
Moreover, overall success of the total intervention strategy, including endoscopic surveillance and concurrent treatment of recurrence, can rectify a relatively high recurrence rate. Our two patients, whose remnant or recurrent adenomas were treated endoscopically, were free of recurrence in further monitoring endoscopies. All recurrences were low-grade displasia and no invasive cancers were detected during follow-up endoscopies.

Polyp morphology and the mucosal aspect may be predictive of submucosal invasion. Moss et al. identified the Paris $0-\mathrm{IIa}+\mathrm{c}$ classification as a risk factor, especially in combination with nongranular surface morphology [7]. However, none of the lesions included in the present study was classified as IIa $+\mathrm{c}$. The mucosal aspect (Kudo pit pattern) of the resected adenoma is routinely assessed and defined for all our lesions. This may reflect the familiarity of endoscopists with dedicated classification systems such as the Kudo pit pattern type. Hence, endoscopists, especially 
those resecting gastrointestinal precancerous lesions, should receive proper training in endoscopic pattern recognition.

In the present study, the small size sample and its retrospective nature present limitations. On the other hand, the predictive value of the Kudo classification, particularly Kudo type 4, in determining adenomatous polyps and cancer risk was analyzed in detail. Also, in contrast to other studies, besides adenomatous polyps, nonadenomatous precancerous lesions such as neuroendocrin tumors and leiomyoms were also analyzed.

In conclusion, we believe EMR to be a safe and feasible procedure for precancerous lesions, with low complication and acceptable recurrence rates. Clearly, the Kudo pit pattern should be considered in assessing cancer risk. Our low recurrence and complication rates also emphasize the importance of training and centralization of this procedure;optimal diagnostic work-up, the possibility of missed remnants, and recurrences during follow-up support this recommendation.

\section{Funding}

This research has received no financial aid from any funding agency or from the public, commercial, or nonprofit sectors.

\section{Conflict of interest}

The authors declare no conflict of interest.

\section{References}

1. Consolo P, Luigiano C, Strangio G, et al. Efficacy, risk factors and complications of endoscopic polypectomy: ten year experience at a single center. World J Gastroenterol 2008; 14: 2364-9.

2. Alexander S, Bourke MJ, Williams SJ, et al. EMR of large, sessile, sporadic nonampullary duodenal adenomas: technical aspects and long-term outcome (with videos). Gastrointest Endosc 2009; 69: 66-73.

3. Bergmann U, Beger HG. Endoscopic mucosal resection for advanced non-polypoid colorectal adenoma and early stage carcinoma. Surg Endosc 2003; 17: 475-9.

4. Yokota T, Sugihara K, Yoshida S. Endoscopic mucosal resection for colorectal neoplastic lesions. Dis Colon Rectum 1994; 37: 1108-11.

5. Winawer SJ, Zauber AG, Ho MN, et al. Prevention of colorectal cancer by colonoscopic polypectomy. The National Polyp Study Workgroup. N Engl J Med 1993; 329: 1977-81.
6. Zauber AG, Winawer SJ, O’Brien MJ, et al. Colonoscopic polypectomy and long-term prevention of colorectal-cancer deaths. N Engl J Med 2012; 366: 687-96. doi: 10.1056/ NEJMoa1100370

7. Woodward TA, Heckman MG, Cleveland P, et al. Predictors of complete endoscopic mucosal resection of flat and depressed gastrointestinal neoplasia of the colon. Am J Gastroenterol 2012; 107: 650-4. doi: 10.1038/ajg.2011.473

8. Buchner AM, Guarner-Argente C, Ginsberg GG. Outcomes of EMR of defiant colorectal lesions directed to an endoscopy referral center. Gastrointest Endosc 2012; 76: 255-63. doi: 10.1016/j.gie.2012.02.060

9. Moss A, Bourke MJ, Williams SJ, et al. Endoscopic mucosal resection outcomes and prediction of submucosal cancer from advanced colonic mucosal neoplasia. Gastroenterology 2011; 140: 1909-18. doi: 10.1053/j.gastro.2011.02.062

10. Barendse RM, van den Broek FJ, Dekker E, et al. Systematic review of endoscopic mucosal resection versus transanal endoscopic microsurgery for large rectal adenomas. Endoscopy 2011; 43: 941-9.

11. Cotton PB, Eisen G, Romagnuolo J, et al. Grading the complexity of endoscopic procedures: results of an ASGE working party. Gastrointest Endosc 2011; 73: 868-74. doi: 10.1016/j.gie.2010.12.036

12. Ponchon T. Endoscopic mucosal resection. J Clin Gastroenterol 2001; 32: 6-10.

13. Binmoeller KF, Bohnacker S, Seifert H, et al. Endoscopic snare excision of "giant" colorectal polyps. Gastrointest Endosc 1996; 43: 183-8.

14. Regula J, Wronska E, Polkowski M, et al. Argon plasma coagulation after piecemeal polypectomy of sessile colorectal adenomas: long-term follow-up study. Endoscopy 2003; 35: 212-8.

15. Stergiou N, Riphaus A, Lange P, et al. Endoscopic snare resection of large colonic polyps: how far can we go? Int $\mathrm{J}$ Colorectal Dis 2003; 18: 131-5.

16. Bories E, Pesenti C, Monges G, et al. Endoscopic mucosal resectio for advanced sessile adenoma and early-stage colorectal carcinoma. Endoscopy 2006; 38: 231-5.

17. Arebi N, Swain D, Suzuki N, et al. Endoscopic mucosal resection of 161 cases of large sessile or flat colorectal polyps. Scand J Gastroenterol 2007; 42: 859-66.

18. Zlatanic J, Waye JD, Kim PS, et al. Large sessile colonic adenomas: use of argon plasma coagulator to supplement piecemeal snare polypectomy. Gastrointest Endosc 1999; 49: $731-5$.

19. Doniec JM, Löhnert MS, Schniewind B, et al. Endoscopic removal of large colorectal polyps: prevention of unnecessary surgery? Dis Colon Rectum 2003; 46: 340-8.

20. Bedogni G, Bertoni G, Ricci E, et al. Colonoscopic excision of large and giant colorectal polyps. Technical implications and results over eight years. Dis Colon Rectum 1986; 29: 831-5.

21. Kanao H, Tanaka S, Oka S, et al. Clinical significance of type $\mathrm{V}(\mathrm{I})$ pit pattern subclassification in determining the depth of invasion of colorectal neoplasms. World J Gastroenterol 2008;14:211-7. 
22. Facciorusso A, Antonino M, Di Maso M, et al. Non-polypoid colorectal neoplasms: Classification, therapy and follow-up. World J Gastroenterol 2015;21:5149-57. doi: 10.3748/wjg. v21.i17.5149

23. Fenger C, Bak M, Kronborg O, Svanholm H. Observer reproducibility in grading dysplasia in colorectal adenomas: comparison between two different grading systems. J Clin Pathol 1990; 43: 320-4.

24. Haggitt RC, Glotzbach RE, Soffer EE, Wruble LD. Prognostic factors in colorectal carcinomas arising in adenomas: implications for lesions removed by endoscopic polypectomy. Gastroenterology 1985; 89: 328-36.

25. Kikuchi R, Takano M, Takagi K, et al. Management of early invasive colorectal cancer. Risk of recurrence and clinical guidelines. Dis Colon Rectum 1995; 38: 1286-95.

26. Lezoche E, Feliciotti F, Paganini AM, et al. Laparoscopic vs open hemicolectomy for colon cancer. Surg Endosc 2002; 16: 596-602.

27. Song JH, Choi YY, An JY, et al. Short-Term Outcomes of Laparoscopic Total Gastrectomy Performed by a Single Surgeon Experienced in Open Gastrectomy: Review of Initial Experience. J Gastric Cancer 2015;15:159-66. doi: 10.5230/jgc.2015.15.3.159

28. Su MY, Hsu CM, Ho YP, et al. Endoscopic mucosal resection for colonic non-polypoid neoplasms. Am J Gastroenterol 2005; 100: 2174-9.
29. Kunihiro M, Tanaka S, Haruma K, et al. Electrocautery snare resection stimulates cellular proliferation of residual colorectal tumor: an increasing gene expression related to tumor growth. Dis Colon Rectum 2000; 43: 1107-15.

30. Espinel J, Pinedo E, Ojeda V, Del Rio MG. Treatment modalities for early gastric cancer. World J Gastrointest Endosc 2015;7:1062-9. doi:10.4253/wjge.v7.i12.1062

31. Alberts DS, Martinez ME, Roe DJ, et al. Lack of effect of a high-fiber cereal supplement on the recurrence of colorectal adenomas. Phoenix Colon Cancer Prevention Physicians' Network. N Engl J Med 2000;342:1156-62.

32. Bonithon-Kopp C, Piard F, Fenger C, et al. Colorectal adenoma characteristics as predictors of recurrence. Dis Colon Rectum 2004; 47: 323-33.

33. Schatzkin A, Lanza E, Corle D, et al. Lack of effect of a lowfat, high-fiber diet on the recurrence of colorectal adenomas. Polyp Prevention Trial Study Group. N Engl J Med 2000; 342:1149-55.

34. Wallace K, Baron JA, Cole BF, et al. Effect of calcium supplementation on the risk of large bowel polyps. J Natl Cancer Inst 2004; 96: 921-5.

35. Brooker JC, Saunders BP, Shah SG, et al. Treatment with argon plasma coagulation reduces recurrence after piecemeal resection of large sessile colonic polyps: A randomized trial and recommendations. Gastrointest Endosc 2002; 55: 371-5. 